\title{
COMPARATIVE ANALYSIS OF THE SUSTAINABLE DEVELOPMENT STRATEGIES AND INDICATORS OF THE V4
}

\author{
Dorottya Edina KOZMA ${ }^{\mathrm{a}}$
}

\author{
a University of Pannonia, 10 Egyetem Street, Veszprém, H-8200. e-mail address: \\ kozmadorottyaedina@gmail.com
}

Cite this article: Kozma, D.E. (2019). Comparative Analysis of the Sustainable Development Strategies and Indicators of the V4. Deturope, 11(2), 101-120.

\begin{abstract}
With the explosive growth of mankind and as a result of the escalating migration wave the European Union attaches greater importance to sustainable development and sustainability. In my study within the European Union, I examine the countries of the Visegrád Four in terms of sustainability. The Visegrád countries (also known as V4) have gone through great changes during the last two decades in case of economic, social and environmental perspectives equally. Incorporating these factors into their sustainable development strategy and their indicator system has been implemented in different ways which can be seen from the year of the development of the strategies. The four countries are investigating great power in sustainable development, so it is essential to examine how the V4 countries could incorporate and apply the goals of sustainable development (EU SDG) and its indicators into the lives of the citizens and in the policies. The most important goal of my study is to identify the similarities and differences in the application of the sustainable development framework strategy and indicator system of the surveyed countries. Do we find any difference from the EU indicators or they are the same in one? I apply a comparative analysis to the illustration that is best able to show the intended purpose. My hypothesis is the following: none of the surveyed Visegrád countries has taken over the European Union's Sustainable Development Indicator System or the SDG indicators. In the first part of the study the EU and country strategies are analyzed while the second part is the analysis of the indicators/indicator systems. The information which is required for the comparison is provided by the European Union, the Czech Republic, Hungary, Poland and Slovakia's Statistical Offices.
\end{abstract}

Key words: Visegrád Four, EU, sustainable development, indicator, indicator system

\section{INTRODUCTION}

If we think about what sustainable development, sustainability concepts mean, when they were first used and under which circumstances developed, we may not be able to give the first thought the answer of these questions. We must go back to history. Rachel Carson, American naturalist, published the first conception of environmental crisis awareness in 1962 in the Silent Spring (Bartus \& Szalai, 2014). The next step was made by the Club of Rome (The Limits to Growth). Their primary purpose was to draw attention to problems in the environment, to examine them and try to develop a solution (Rosta, 2008).

The first solution was set up at the 1972 Stockholm Conference (UN Conference on the Human Environment), which adopted a Declaration on the Principles of Environmental 
Protection and international tasks. As a result of this, change of attitude has taken place (Láng, 2001). The formation of sustainable development concept and definition were connected with the United Nations Commission on Environment and Development (Brundtland Commission). First appeared in 1987 in Our Common Future. The concept was determined as follows: "Development which meets the needs of current generations without compromising the ability of future generations to meet their own needs." (WCED, 1987). In essence, the work of Brundtland Commission has brought a breakthrough success in sustainability. Timely next conferences and world meetings (Rio de Janeiro - 1992, Johannesburg - 2002) took onward the concept of Brundtland Commission (Láng, 2001). The Rio de Janeiro Conference (United Nations Conference on Environment and Development - UNCED) encouraged people to protect their environment while Johannesburg Conference (World Summit on Sustainable Development - WSSD) was a kind of further developed version. The Rio+20 conference (UN Conference on Sustainable Development) was built on three previous conferences (Stockholm, Rio, Johannesburg). This conference gives the background of the sustainable developments new, global architecture (Zolcerova, 2016).

In 2015 it was necessary to renegotiate future objectives. It was located in Paris where 193 United Nation members gathered to discuss the new sustainability program, resulting in the AGENDA 2030 for Sustainable Development. They have been formulated 17 goals (SDG Sustainable Development Goals) on the basis of which the European Union has developed its new sustainable development indicators.

With the reviews of these it becomes visible what is the meaning of sustainable development (definition) nowadays and under what circumstances have been developed. Sustainable development features the quality of life. For the whole world it is a typical problem that in several places the population lives in unequal economic and social conditions. As far as we can take advantage of our environment, whether we know our stocks are limited to some extent, not all the factors have been an alternative. Consequently, the main purpose of my study is to determine how similarities and differences were found in the application of the Sustainable Development Framework Strategy and indicators system of the countries (V4).

\section{THEORETICAL BACKGROUND}

Hungary, the Czech Republic, Poland and Slovakia (group of V4) have a long-term past in all historical, economic and cultural perspective (Káposzta \& Nagy, 2015). In the past and present these countries represented/represent a civilization based on social and cultural roots (Brokešová \& Vachálková, 2016). The background of my study is the review and examination 
of the Visegrád Four countries and the European Union's sustainable development framework strategy. The examination of the countries' sustainable development strategies are inevitable to understand what objectives and indicators have been set. Unfortunately, in my own previous research I have been assured that a country set up its goals for sustainable development does not mean that it clearly states what indicators it uses.

\section{Research question and hypothesis}

During the study my main purpose is to determine what similarities and differences can be found in the surveyed EU member states or if we want to define in another way in sustainable development framework strategies and indicator systems of the Visegrád Fours. Based on this, I have determined my research question as follows:

Q: To what extent do the surveyed Member States use the indicators of the SDIs or SDGs developed by the European Union? Did they build into their strategies in the same way or are they using their own systems?

To answer this question, it is necessary to examine the country's sustainable development strategy which takes place in the second chapter. Naturally, it is also necessary to comprehensively study the sustainability indicators and indexes of the Visegrád Four countries. In these, the SDIs and SDG system are providing a comparison basis and great help as well as the countries sustainable development strategies which contain and identify the indicators. In case of the Czech Republic the Czech Republic Strategy for SD, in Hungary the Sustainable Development Framework Strategy, in Poland the SD Strategy for Poland up to 2025 - Polska 2025 while in Slovakia the National Strategy for SD for the Slovak Republic. For those countries which developed their own indicators the statistical office plays an important role. They are providing the datas to the development of the indicators. My hypothesis is the following: H: None of the surveyed Visegrád countries has taken over the European Union's Sustainable Development Indicator System or the SDG indicators. In each case it serves as a kind of comparison basis.

The answer of the research question and hypothesis will be shown after the presentation of the Visegrád Four's sustainable development indicators because it would be impossible without the overview of the systems.

\section{The sustainable development strategy of the European Union as a starting point}

In the last decades, years several researches, publications, analysis and comparisons appeared in case of sustainable development. What does sustainable development mean? As we can not 
easily answer what is the meaning of sustainable development, the formulation of the strategy is not simple either. The countries involved in the examination - Hungary, the Czech Republic, Poland and Slovakia - its sustainable development strategy or action plan is largely linked to the strategy which was developed by the European Union. This connection is also good because when all of the 28 European Union member states developed their strategies this gave them a kind of basis.

When can we say that the European Union has a sustainable development strategy? The first steps to develop the strategy were made during the Helsinki Summit (1999) (Magyar Természetvédők Szövetsége, 2005) and the final touches were done in 2001. From that date we count on the implementation of the action plan. The European Union Sustainable Development Strategy was finally adopted at the Göteborg European Council (Fischer et al., 2013). This means that the Lisbon Strategy was completed with the third dimension which is the environmental dimension (Schmuck, 2002). The sustainability strategy of the European Union is a three-pillar strategy. If we draw up a parallel with the work of Brundtland Commission in line with the concept of sustainable development that may formulate, we are certainly talking about a long-term strategy which affects the three dimensions. At the same time coordinates the appropriate policies in order to meet the present and future generation needs and provide these generations a better standard of living and prosperity (European Council Göteborg, 2001). Based on these the following long-term goals are named:

- fight against climate change, global poverty, social exclusion, ageing;

- sustainable transport, production and consumption;

- proper management of natural resources;

- public health (Puşcaciu, Puşcaciu \& Puşcaciu, 2016).

Following the presentation of the strategy in 2001, it was reviewed in 2006 and then in 2009. These revisions complemented new targets which were adjusted to the sustainable development indicators.

\section{Sustainable development strategy of the V4's}

In the 20th century, sustainability was a major issue as it is today and is believed to have developed as a result of increased resources use during the Industrial Revolution. With the rapid growth of the population the challanges and needs will increase significantly (Štreimikiene, Mikalauskiene \& Mikalauskas, 2016). In the Czech Republic sustainable development is primarly assessed at national level. Three years after the European Union's strategy was established the Czech Government adopted the country's sustainable development strategy, 
the official name is: Czech Republic Strategy for Sustainable Development. It is a framework for the development of various policies and similar official documents which includes sectoral policies and action programs. It serves as a basis for strategic decision-making: in each sector and in inter-sector cooperation as well as in cooperation with other interest groups. It aims to identify the most important strategic sub-objectives, goals and tools that are designed to eliminate the weightlessness problems in each sustainability pillar (Office of the Government of the Czech Republic, 2006). The framework strategy concentrates on the following areas:

- competitiveness of the economy; stability and cohesion;

- landscape, natural resources and environmental protection;

- research, development, education; European and international context;

- good governance (Fischer et al., 2013).

Based on the Brundtland Commission's definition the focus of the planning is to ensure the best possible quality of life for todays' generations and to create high level quality conditions for future generations. Today, the last 2010 Czech sustainable development name five key priority axes which are also the strategic vision of sustainable development: 1. society, people and health; 2. economy and innovation; 3. spatial development; 4. landscape, ecosystems and biodiversity; 5. a stable and secure society (Ministry of the Environment of the Czech Republic, 2010).

Similarly to the Czech Republic, Hungary developed its first sustainable development strategy in 2007 after joining the European Union. The European Union gives free hand to the Member States to develop their sustainable development strategy which summarizing their own goals and priorities. In case of Hungary it is true that the first strategy (National Sustainable Development Strategy) was completed in 2007 but there were many preliminary ambitions for sustainability. There were essentially not yet concrete strategies but plans, drafts (NFÜ, 2007). The focus point is to develop sustainability priority objectives. The assessment of unsustainable processes, the Future Finding - the assessment of the National Sustainable Development Council started the establishment of the second action plan or the so-called framework strategy. Hungary's second sustainable development strategy was published in 2013 covering the period from 2012 to 2024 (Kis-Orloczki, 2014). The main goal is to recognize the so-called lending process of future generations as well as comit themselves to presenting conditions of natural resources of the state and how these could be used to develop the maintenance system (NFFT, 2013). 
The interpretation of the strategy is much narrower if we compare with the sustainability strategy of the European Union. From a political view sustainable development is a long-term activity referring to resource management (Bartus, 2013). Solving the problems are not necessarily just the task of political government. In order to be able to solve them we must involve families and businesses alike. When we compare it to the European Union's strategy we can only find difference between the three dimensions (economic, social and environmental). In case of Hungary the three dimensions are supplemented with one additional which is the human dimension. The overall goal of Hungary's sustainable development framework strategy is to create and secure the conditions for continuous adaptation for all sustainability dimensions. In addition, it should be able to ensure that cultural adaptation is improved (NFFT, 2013).

The transitional countries (eg. Lithuania, Poland and Latvia) have had special motivation in preparation of national sustainable development strategies. Why is it important for them? The answer seems clear as these countries seek to reverse the negative economic, social and environmental trends of the past by creating a strategy (Ruotsalainen, 2005). As the countries of the Visegrád Four, Poland was the first that developed a sustainable development strategy in the spirit of the millenium (2000) which is essentially a long-term strategy for sustainable development (Kis-Orloczki, 2014). In Poland the conception of development is a constitutional principle. The 5th Article of the Polish Constitution (2. April 1997) contains the principle of sustainable development (Urbaniec, 2015). On this basis, sustainable development is considered as a socio-economic development in which the integration of political, economic and social actions take place. The NSDS ${ }^{17}$ of Poland (Sustainable Development Strategy for Poland up to $2025 \sim$ Polska 2025) typically analysis the changes since the transition to the market economy. The main goal of the strategy is to reverse the negative tendencies of the past. Another objective of the strategy is to provide Polish families with welfare growth and to minimize development gaps against developed countries. Naturally, taking into account the three dimensions of sustainability (Ruotsalainen, 2005). It is a very important factor to do these goals by taking into account the current status of the Polish economy as well as the consequences of Polish law and the concepts they formulate (Zuzek, 2007). Similarly like Hungary and the Czech Republic's sustainability program, it is a long-term, multidimensional framework program which presents a general vision of the future Poland. It also provides guidance on how to revise sectoral and regional plans, programs and policies in order to strive

\footnotetext{
${ }^{17}$ NSDS - National Sustainable Development Strategy
} 
for sustainability. The country's sustainable development strategy is complemented by two additional areas which are the political and institutional dimensions (Urbaniec, 2015).

The Slovak economy can be referred to like one of the most dinamically developing economies in the euro zone. It is approaching very fast to the standard of living of the OECD economies but it is often not the easiest to implement. The Slovak Government adopted the sustainability strategy on 10 October 2001 and by the National Council on 3 April 2002 (Koločány, 2014). Sustainable development is regulated in the 6th Article of Law 17/1992. Similarly to the other surveyed countries, the sustainability strategy is based on the definition of Brundtland Commission and formed on the three dimensions (economic, social, environmental) and it is complemented by more such as culture (Kis-Orloczki, 2014). From an economic point of view, the emphasis is placed on the effective use of natural resources as well as the pursuit of economic development which is consistent with the conservation of natural resources. If we look at sustainability from a social view of point the goal is to provide the socalled respectable life for the population and distribute income from resources equally between groups of society (Izakovičová \& Oszlányi, 2009). The sustainable development strategy set out two Action Plans for the period after 2000. One between 2005 and 2010 ("Action Plan for Sustainable Development") and the other between 2007 and 2013. The "Action Plan for Sustainable Development" covers the period of 2005-2010 in which the implementation of sustainable development is included in sectoral policies. They would like to use environmentally friendly technologies and to reduce the rate of waste generation in the territory of the Slovak Republic. Further orientation is to promote financial instruments, to educate the population on how to resonably use and protect natural resources in favor of sustainable development. Priority will also be given to the development of the information society, sustainable mobility and urban renewals. The horizontal priority objectives for sustainable development 2007-2013 are to support all three pillars of sustainable development from the National Reference Framework. Of course, this must be consistent with the objectives and the indicators of the European Union Sustainability Strategy. Cumulatively, it focuses on intelligent and inclusive growth and respects the economic, social and environmental dimensions (Koločány, 2014).

\section{The summary of the examined sustainable development strategies}

Overall, looking back to the sustainable development strategies of the four countries - the Czech Republic, Hungary, Poland and Slovakia - we can conclude that each country has its own characteristics of sustainability. There are even bigger differences compared to the 
European Union's strategy but the fact that the countries have to rely on the EU at some level. The similarities and differences of the strategies are summarized in Tab. 1.

Table 1 Summary of the surveyed countries' strategies

\begin{tabular}{|c|c|c|c|c|c|}
\hline & $\begin{array}{c}\text { European } \\
\text { Union }\end{array}$ & $\begin{array}{l}\text { The Czech } \\
\text { Republic }\end{array}$ & Hungary & Poland & Slovakia \\
\hline $\begin{array}{c}\text { Name of the } \\
\text { strategy }\end{array}$ & $\begin{array}{c}\text {-Sustainable } \\
\text { Development } \\
\text { Strategy } \\
\text {-Agenda } \\
2030\end{array}$ & $\begin{array}{c}\text { Czech } \\
\text { Republic } \\
\text { Strategy for } \\
\text { SD }\end{array}$ & $\begin{array}{l}\text { Fenntartható } \\
\text { Fejlődési } \\
\text { Keretstratégia }\end{array}$ & $\begin{array}{l}\text { SD Strategy } \\
\text { for Poland } \\
\text { up to } 2025- \\
\text { Polska } 2025\end{array}$ & $\begin{array}{l}\text { National } \\
\text { Strategy for } \\
\text { SD for the } \\
\text { Slovak } \\
\text { Republic }\end{array}$ \\
\hline $\begin{array}{c}\text { Year of } \\
\text { publication }\end{array}$ & $\begin{array}{l}\bullet 2001 \\
\bullet 2015\end{array}$ & 2004 & 2007 & 2000 & 2001 \\
\hline $\begin{array}{c}\text { Year of } \\
\text { modification }\end{array}$ & 2006 & 2010 & 2013 & 2000 & 2001 \\
\hline $\begin{array}{c}\text { Number of } \\
\text { modifications }\end{array}$ & 1 & 1 & 1 & 0 & 0 \\
\hline Pillars & $3+1$ & $3+3$ & $3+1$ & $3+2$ & $3+1$ \\
\hline
\end{tabular}

Source: By the author, based on Kis-Orloczki (2014)

What are these similarities and differences? The most important similarity is that each state has developed its own strategy and in each case it has been developed by the 1992 Rio Conference as well as the indicators. A difference can be seen in the year of publication, sustainability goals, objectives and implementation time.

\section{DATA AND METHODS}

Earlier until 2015-2016 the European Union used the European Union Sustainable Development Indicator System (EU SDIs) to measure sustainable development. Nevertheless, the AGENDA 2030 for Sustainable Development which was presented in the framework of the United Nations Climate Change Conference (2015, Paris) has developed new indicators for sustainable development. This system is well situated to evaluate the performance and progress of member countries both methodically and statistically. Data which is required for the indicators can be assessed on EUROSTAT's website from 2007 and includes datas form all 28 Member States. However, we can not ignore the old system anyway. The SDIs and SDG system are providing a comparison basis and great help as well as the countries sustainable development strategies which contain and identify the indicators.. Moreover, of course each country has developed the most appropriate indicators for its own goals, objectives and progress plan which can be said to be country specific. Overally, the indicators are intended to show the achievement of countries in their own sustainable development indicator systems. In case of 
the Czech Republic the Czech Republic Strategy for SD, in Hungary the Sustainable Development Framework Strategy, in Poland the SD Strategy for Poland up to 2025 - Polska 2025 while in Slovakia the National Strategy for SD for the Slovak Republic. For those countries which developed their own indicators the statistical office plays an important role. In my study I would like to present the sustainable development indicators of the surveyed countries - the Czech Republic, Hungary, Poland and Slovakia - in a comparative analysis. We can not use other methods because the similarities and differences of the indicators/indicator systems can not be identified by other technique. It is not possible to show in any other way because there are no methods which concentrate on specific features.

\section{RESULTS}

During the presentation of the definition and concept of sustainable development became visible that the mankind began to recognize unsustainable processes and problems from the 1960s. Hungary, the Czech Republic, Poland and Slovakia - group of V4 - have a long-term past in all historical, economic and cultural perspective. Similar concentrations have emerged in the analysis of the countries' sustainable development strategies whereas in all four cases, the 1992 Rio Declaration commitments launched the process of developing sustainable development strategies. We can consider the European Union's Sustainable Development Strategy as a starting point that has given the Member States a proper background for their own national strategies.

Different words are used in the literature to formulate the indicator word. Basically if we strive for simplicity when defining this concept, the indicator word is dependent on many factors. It expresses some kind of change that reflects its degree and the related features. For the given phenomenon it shows the properties of the phenomenon as well as helps to getting through and last but not least based on these features make the phenomenon comparable (Havasi, 2007). The definition of sustainable development indicators are based on different specifications of development concepts. We call development concepts those plan documents (strategies, programs) that are designed to track the implementation of the project (Central Statistical Office, 2011). They can be at local, regional and national levels as well as at the European Union's level. The primary role of sustainable development indicators is the operationalization of sustainable development at local, regional and national leves in order to monitor the various plan documents (Urbaniec, 2015). 


\section{Indicators for Sustainable Development in the European Union}

The European Union has used its own SDIs for measuring and demonstrating sustainability target for the period of 2015-2016. This is essentially the time when AGENDA 2030 has not yet come to the fore for sustainable development. The purpose of the former system - EU SDIs - was to show how far the Member States of the European Union have progressed to achieve their goals which are esentially described by the EU SDS (Sustainable Development Strategy). The strategy and the indicators were adopted at the same time at the Göteborg Summit (2001) by the Commission in 2005 (Stănciulescu \& Bulin, 2012). The European Union's SDI system contains nearly 130 indicators. The main indicators can be divided into additional operational, explanatory and contextual indicators that are built in a pyramid shape. All in all they can be split up into three main and one additional levels (Eurostat, 2015).

AGENDA 2030 for Sustainable Development is a strategy for the eradiction of poverty and the promotion of sustainable development. This strategy is tangible and must be consistent with measures that addresses a wider range of social needs and promote the creation of fair, peaceful, inclusive societies and also protect them. In addition, they naturally protect the environment and they give help in managing climate change. From the part of the European Union, the EUROPE 2020 strategy played an important role in the development of AGENDA 2030. The European Commission has undertaken to monitor the development of the objectives for sustainable development. It is not binding on UN members but it is a requirement that governments undertake and set up at national level the backdrop for achieving the 17 goals (Eurostat, 2017). The strategy developed indicators for all 17 goals and for the 169 objectives which are in association with them. The indicators are revised by the UN Statistical Commission. It is important to note that the indicators of AGENDA 2030 are in line with the UN Global Indicator list. It also contains indicators that are specifically EU-specific and suitable for incorporating into the EU's various, long-term policies. The set of indicators adopted in 2016 contains totally 244 different indicators covering the 169 goals (Griggs et al., 2014). These indexes cover the three dimensions of the Brundtland Commission's concept and one more institutional dimension. Depending on their rating, the indicators are divided into two groups: show a longer or short term trend. The long term indicators focus on the last 15 years (2000-2015, 2011-2016) and at least 10 years of data are available. Short time indicators cover the past 5 years $(2010-2015,2011-2016)$ but are available for at least 3 consecutive years (Eurostat, 2017). 


\section{Sustainable development indicators in the V4}

In case of the Czech Republic, we can divide the indicators in two ways. The first splitting method is based on the three dimensions of sustainable development (economic, social, environmental) and three addtional dimensions (research, development, education; European and international context; good governance). In this case we can speak about 34 aggregated indicators (Government Council for SD - Ministry of the Environment, 2009). While the collection of country-wide indicators is not a problem we must not forget the fact that the examination of lower levels of public administration can cause some sort of headache (Fischer et al., 2013). If we divide the Czech Republic's sustainable development indicators into the five main priority axes at the same time, we get completely different indicators. Their number (47 indicators) is not the same as the dimension based resolution. The currently used Czech Strategy contains 47 indicators that are closely to achieving each strategic goal. Essentially for communication purpose they use the 34 aggregated indicators (Ministry of the Environment of the Czech Republic, 2010).

Until the appearance of the second framework strategy in 2013, Hungary used the indicators divided by the EUROSTAT. The indicators were identical with the EU SDIs. By developing the strategy, they have completely revised the indicators and made them country specific. Every two year the so-called "Progress Report" will be published in which the indicators are reviewed. The National Sustainable Development Council adopted the first report on 3 December 2015 in which 16 key indicators are named with additional and context indicators (KSH, 2017). Totally, 103 indicators can be identified in Hungary which can be divided according to the $3+$ 1 dimension of sustainability: 23 economic, 13 social, 41 environmental and 26 human (KorsósSchlesser \& Marselek, 2016). Further splitting of the indicators can also be made depending on which one is considered a true indicator and which is only a background indicator. Based on these, we distinguish 82 real indicators. They are characterized by both positive and negative comparisons. In the other group there are 21 background indicators that provide mainly structural information. There are indicators from which no time series can be set up. With this kind of transformation, such as the fact that the Statistical Office differ from the system (EU SDIs) developed by the European Union there are indicators that we can not compare with EUROSTAT indicators. These indicators are household indebtedness rate or NGOs. However, it is not a "unique" feature. We have experienced these inconsistencies even in the first examined country (the Czech Republic). We will experience in the countries that are being examined. Since the strategy was developed in a timely manner rather than the adoption of 
SDGs, the progress report goals are not linked to SDG. Indicators will only follow these goals in the future (KSH, 2017).

Poland's Sustainable Development Strategy tells us one in one how many indicators are "managed" by the country, how many indicators are used to measure the goals and objectives of sustainable development. In Poland sustainable development indicators can be separated on the basis of three dimensions of sustainable (economic, social, environmental) and two additional dimensions (political, institutional) (Central Statistical Office, 2011). Based on these, the country totally manages 76 indicators. Among the countries have studied so far, Poland and the Czech Republic have the least sustainable development indicators. Hungary is an exception in this respect, as there are 103 sustainability indicators for the country. Based on the above, we can conclude that the sustainability strategies of the countries have been greatly influenced by the Brundtland Commission's sustainable development concept. We can break down the indicators of all three countries by the three basic dimensions (economic, social, environmental) and in some cases based on the addtional dimensions.

The introduction of sustainable development indicators in Slovakia was largely influenced by the indicators developed by the Commission. This set of indicator contains in total 134 indicators that can be separated by the $3+1$ dimensions: 23 economic, 41 social, 55 environmental and 15 institutional. The indicators listed here were tested in 22 countries between 1997 and 1999, including Slovakia as well. Their main purpose is to provide the countries the appropriate indicators for measuring sustainability. The secondary objective is to create a better statistical evaluation. Statistical evaluation is an important aspect namely national characteristics largely determine the evaluation of a country (Lyytimäki et al., 2011). As a result of this process in 1997 the Government of Slovakia approved the use of AGENDA 21 as well as the use of indicators. Slovakia defined first its own indicators. This does not really mean the development of fully independent indicators but the adoption of relevant indicators to the country (125 out of 134). At present, indicators for sustainable development are reviewed by the Slovak Statistical Office and the Environment Agency. The Government and other agencies are responsible for issuing databases. The indicators used today are the result of several organizations, programs and conferences, such as AGENDA 21, Rio +10 processes or the Lisbon Strategy (Zolcerova, 2016). In Slovakia all the indicators which are in the "circulation" can be splitted down by four dimensions. From all of the national indicators 32 are more or less correspond to the indicators which are used by the European Union. In case of institutional indicators from three indicators two correspond, while the proportion in socioeconomic indicators are half. The most significant differences can be seen in environmental indicators because of these (65) are only 16 similar to those of the European Union. 
Unfortunately, the list of indicators can not be found either in the country's sustainable development strategy or in any other area.

\section{The results of the research question and the hypothesis}

Overall, it can be concluded that in the examined countries (V4) Slovakia is the only one country that does not name the indicators one in one. We can not find the indicators anywhere. All other sustainability strategies outline how they measure and evaluate sustainable development. Typically, indicators are divided by sustainability dimensions and they are country specific. In Hungary there are 103 indicators, in Slovakia 92, in case of Poland 76 while in the Czech Republic 34 aggregated indicators.

During the presentation of sustainable development framework stategies and indicators obvious facts have become visible. They have shown the fact that they are suitable for answering the research question and the hypothesis. Based on these, my answer to the research question is the following.

To what extent do the surveyed Member States use the indicators of the SDIs or SDGs developed by the European Union? Did they build into their strategies in the same way or are they using their own systems?

It can be concluded that from the countries of Visegrád Four group none of them are fully used the SDIs or SDGs developed by the European Union. In the beginning the EU SDIs provided great help to countries to develop their own indicators. In case of Hungary you can see the most that initially in the strategy set up in 2007, they relied entirely on the European Union indicators. Then in 2013 at the time of the second framework strategy they changed this practice and developed their own indicator system by the help of Central Statistical Office (KSH). This system contains and uses numerically fewer indicators. In the Czech Republic there is already a deviation from the EU. There are very few indicators we can find only 34 aggregate indicators in the strategy if we divide them according to the dimensions of sustainable development. This is also the case with the second modal split which divides the indicators according to the five main priority axes. The situation in Poland and Slovakia is no different from this point of view. Slovakia is closer to the EU indicators because the country had great importance in the development of the indicators of the sustainability strategy. The indicators used by V4 are summarized in Tab. 2. 
Table 2 Sustainable development indicators of V4 countries

\begin{tabular}{|c|c|c|c|c|c|}
\hline & $\begin{array}{c}\text { European } \\
\text { Union }\end{array}$ & $\begin{array}{l}\text { The Czech } \\
\text { Republic }\end{array}$ & Hungary & Poland & Slovakia \\
\hline $\begin{array}{l}\text { Name of } \\
\text { the } \\
\text { strategy }\end{array}$ & $\begin{array}{c}\text { - Sustainable } \\
\text { Development } \\
\text { Strategy } \\
\text {-Agenda } 2030\end{array}$ & $\begin{array}{c}\text { Czech } \\
\text { Republic } \\
\text { Strategy for } \\
\text { SD }\end{array}$ & $\begin{array}{l}\text { Fenntartható } \\
\text { Fejlődési } \\
\text { Keretstratégia }\end{array}$ & $\begin{array}{l}\text { SD Strategy } \\
\text { for Poland up } \\
\text { to } 2025- \\
\text { Polska } 2025\end{array}$ & $\begin{array}{c}\text { National } \\
\text { Strategy for SD } \\
\text { for the Slovak } \\
\text { Republic }\end{array}$ \\
\hline Pillars & $\begin{array}{c}\cdot 3+1 \\
\bullet 17 \text { goals }\end{array}$ & $3+3$ & $3+1$ & $3+2$ & $3+1$ \\
\hline $\begin{array}{l}\text { The way } \\
\text { of } \\
\text { resolution } \\
\text { the } \\
\text { indicators }\end{array}$ & $\begin{array}{c}\cdot \text { EU SDIs }-3+1 \\
\text { dim. } \\
\cdot \text { Agenda } 2030- \\
17 \text { goals }\end{array}$ & $\begin{array}{l}\cdot 3+3 \text { pillar } \\
\cdot 5 \text { main } \\
\text { priority axis }\end{array}$ & $\begin{array}{l}3+1 \text { dimensions } \\
\text { (resources) }\end{array}$ & $\begin{array}{c}3+2 \\
\text { dimensions } \\
\text { (domains) }\end{array}$ & $\begin{array}{l}\text { - Indicators of } \\
\text { Commission } \\
(3+1 \text { dim. }) \\
\text {-Environmental } \\
\text { Agency }(3+1 \\
\text { dimensions })\end{array}$ \\
\hline $\begin{array}{c}\text { Number } \\
\text { of } \\
\text { indicators }\end{array}$ & $\begin{array}{l}\text { - Theme 1. (17) } \\
\text { - Theme 2. (20) } \\
\text { - Theme 3. (19) } \\
\text { - Theme 4. (13) } \\
\text { - Theme 5. (10) } \\
\text { - Theme 6. (12) } \\
\text { - Theme 7. (12) } \\
\text { - Theme 8. (10) } \\
\text { - Theme 9. (13) } \\
\text { - Theme 10. (6) }\end{array}$ & $\begin{array}{c}\bullet \text { Economic } \\
\text { pillar (8) } \\
\cdot \text { Social pillar } \\
\quad(10) \\
\cdot \text { Environment } \\
\text { al pillar (7) } \\
\bullet \text { R\&D, } \\
\text { education (3) } \\
\text { - European and } \\
\text { international } \\
\text { context (1) } \\
\bullet \text { Good } \\
\text { governance (5) }\end{array}$ & $\begin{array}{l}\bullet \text { Economic } \\
\text { resources (23) } \\
\bullet \text { Social } \\
\text { resources (13) } \\
\cdot \text { Environmental } \\
\text { resources (41) } \\
\bullet \text { Human } \\
\text { resources (26) }\end{array}$ & $\begin{array}{c}\bullet \text { Social } \\
\text { domain }(26) \\
\bullet \text { Economic } \\
\text { domain (19) } \\
\cdot \text { Environmen- } \\
\text { tal domain } \\
(24) \\
\text {-Institutional } \\
\text { and political } \\
\text { domain }(7)\end{array}$ & $\begin{array}{c}\text { Indicators of } \\
\text { Commission: } \\
\bullet \text { Economic } \\
\text { dimension }(23) \\
\bullet \text { Social } \\
\text { dimension }(41) \\
\cdot \text { Environmen- } \\
\text { tal dimension } \\
(55) \\
\bullet \text { Institutional } \\
\text { dimension (15) }\end{array}$ \\
\hline & 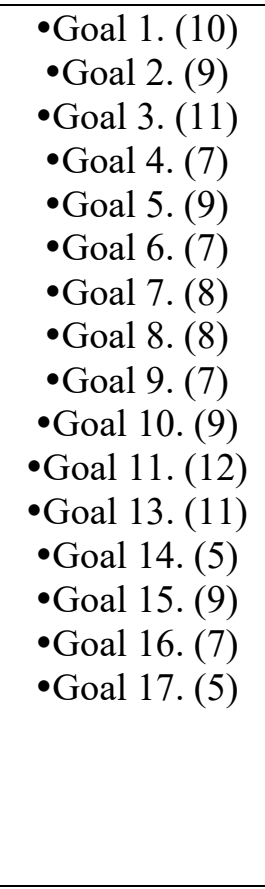 & $\begin{array}{c}\bullet \text { Axis } 1 .- \\
\text { society and } \\
\text { health (7) } \\
\text { •Axis } 2 .- \\
\text { Economy and } \\
\text { innovation } \\
(13) \\
\text {-Axis 3.- } \\
\text { Spatial } \\
\text { development } \\
\text { (12) } \\
\text { •Axis 4. - } \\
\text { Landscape, } \\
\text { ecosystems } \\
\text { and diversity } \\
\text { (7) } \\
\text {-Axis 5. - A } \\
\text { stable and } \\
\text { secure society } \\
(8)\end{array}$ & & & $\begin{array}{c}\text { Environmental } \\
\text { Agency's } \\
\text { indicators: } \\
\text { •Social (9) } \\
\text { •Environmental } \\
(65) \\
\text {-Economic } \\
\text { (15) } \\
\text {-Institutional } \\
\text { (3) }\end{array}$ \\
\hline
\end{tabular}

Source: By the author, based on Griggs et al. (2014), Ministry of the Environment of the Czech Republic (2010), KSH (2017), Central Statistical Office (2011), Zolcerova (2016)

By not taking over one in one the SDIs or SDG indicators used by the European Union, nevertheless they are required to provide datas to EUROSTAT on the measurement of 
sustainability. The other factor that may have contributed to the fact that none of the surveyed countries has taken over the mentioned systems that the European Union has not made it binding on any country. They are free to choose whether to apply or not. From the detailed study of the indicators we can see that countries do not use $100 \%$ of the indicators but at some levels they are using the EU indicators. There are indicators for which the V4 countries have not developed their own indicators. Overall, it can be said that countries can only be compared based on EU SDIs or SDGs.

None of the surveyed Visegrád countries has taken over the European Union's Sustainable Development Indicator System or the SDG indicators. In each case it serves as a kind of comparison basis.

To this assumption the answer became visible during the research question. The benchmark will happen that all 28 European Union Member States are required to provide datas to EUROSTAT. The Member States are needed to become measurable and at the same time comparable in achieving their objectives. Before 2015-2016 the main part of the studies were based on the EU SDIs because it was the only system, set of indicators that contained complete all the datas which were needed for the analysis and evaluations. This situation has changed when the AGENDA 2030 for Sustainable Development and the related 17 goals been developed as a result of the 2015 Paris Climate Convention. The 17 targets can be characterized by about 244 indicators, of which 144 are relevant for the European Union. With these another system was developed to provide basis for comparison for research and analysis. If we should analyze the surveyed Member States based on the self-developed indicator systems, we would encounter the problem of incompatibility. These systems are country-specific and the countries have been developed on the basis of their own objectives. Of course, there are indicators that can be found in every strategy (eg. GDP), there are more or less comparable and have the "worst category" that is totally incomparable. As a thesis, it is possible to state that all EU Member States are obliged to provide datas to the current SDG indicators, so my assumption is true. Indeed, the SDG system forms a kind of comparison basis because that is the only way to allow equal comparisons between Member States.

\section{DISCUSSION}

Comparing the sustainability indicators of the V4 countries with those of the EU SDIs and SDGs, I concluded that the indicators used by the countries and the two EU systems minimally resemble to each other. In case of the Czech Republic 16-16 (both grouping modes), in relation to Hungary 37, while only 25 of the Polish indicators are similar to the EU SDG indicators. In 
total, it can be said that just five indicators are fully common, such as: GDP, general government debt, long-term unemployment rate, greenhouse gas emission and areas under organic farming. The previously used EU SDIs also showed similar results as a comparison. It can be said that the 43 indicators of the indicator system used by Hungary result in the highest degree of similarity, followed by Poland with 34, while the Czech Republic with 15 and 21 indicators. The one in one used indexes are the following: GDP, energy intensity of the economy, total unemployment rate and the areas under organic farming. Figure 1 shows the numerical consistency of the indicators.

Figure 1. The number of identical indicators
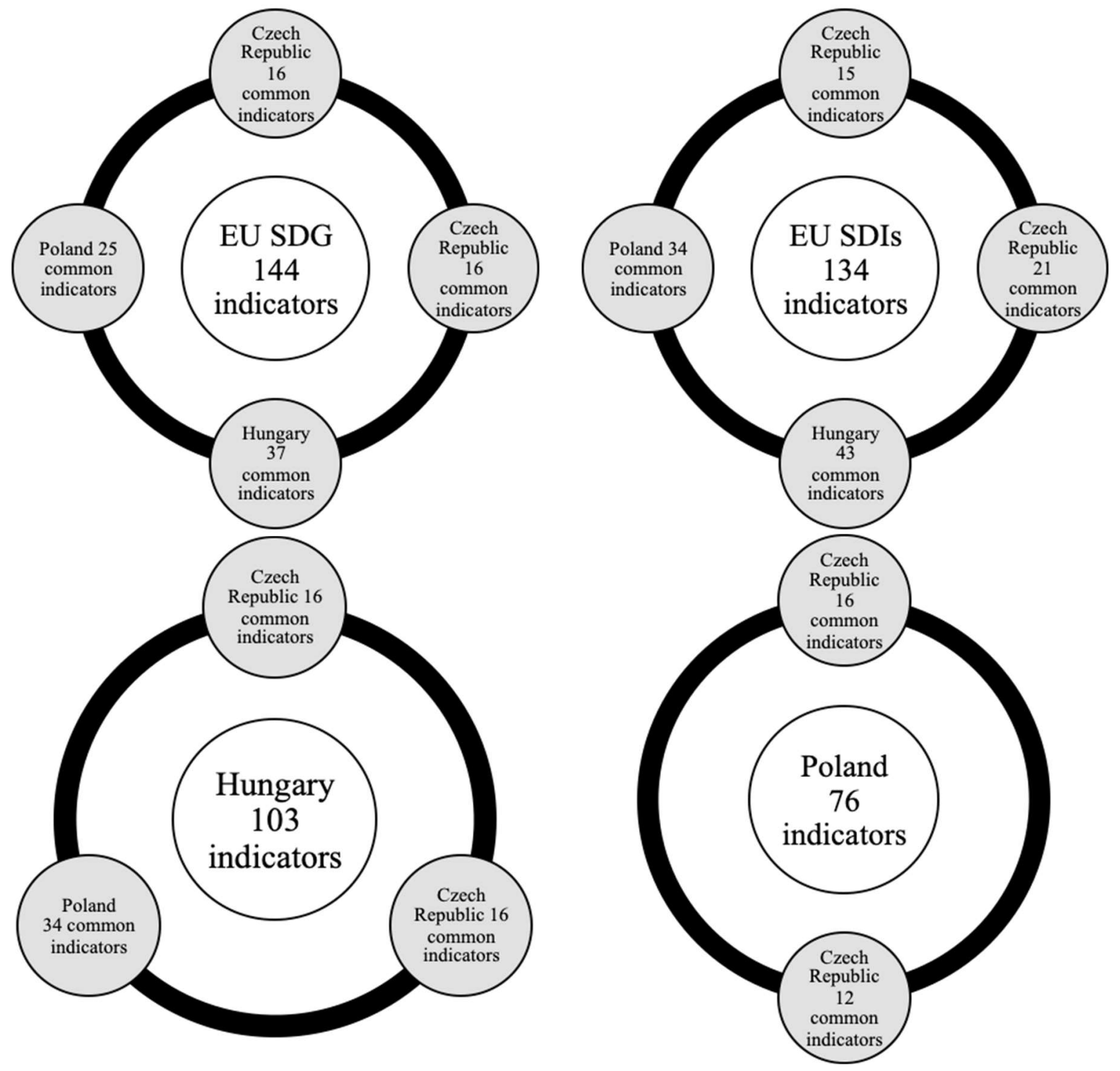

Source: By the author, based on Eurostat (2015), Griggs et al. (2014), Ministry of the Environment of the Czech Republic (2010), Korsós-Schlesser \& Marselek (2016), Central Statistical Office (2011) 
In addition to comparing with the EU indicator systems, I also made a comparison between the countries. Based on these, I examined the similarities and differences of the indicator systems of Hungary and Poland, Hungary and the Czech Republic, as well as Poland and the Czech Republic. In any case, I could draw the conclusion that none of the systems completely covers the other. Common indicators are: energy intensity, greenhouse gas emissions, GDP, government debt, R\&D, labor productivity, unemployment rate. I could draw similar conclusions when comparing the Czech Republic and Poland. A total of 10 indicators are equal to $100 \%$, such as life expectancy, energy intensity of the economy, GDP. In case of Slovakia I could not compare the indicators of sustainability with the other surveyed countries and the European Union because the strategy does not name them.

In my comparative analysis, it became even more apparent that the surveyed Visegrád countries used the indicator systems of the European Union only as a basis for developing their own systems. Numerical analyses can only be carried out on the basis of the EU SDG. In every case, the basis of the country strategies can be traced back to the sustainable development concept and definition of the Brundtland Commission.

\section{CONCLUSION}

In my paper, I tried to find an answer, how the Visegrad Four applied the European Union's sustainability strategy and to what extent were integrated the EU SDIs or SDG indicators into their indicator system. It can be simply phrased what are the similarities and differences between the surveyed countries - the Czech Republic, Hungary, Poland and Slovakia - in their sustainable development strategies and indicator systems. It has been proved that the examination of country-specific strategies is indispensable for the subsequent examination of sustainability indicators. The V4s are completely different from the EU strategy. The strategy of the European Union provided them only a basis to develop their own system. Due to the differences that is why the comparison of the surveyed countries is very difficult. During the research work which preceded the study, it has become apparent that after the Paris Climate Convention in 2015 the European Union does not measure the progress of the sustainable development objectives by the EU SDIs but by the SDG (sustainable development goals). More specifically with the related indicators. These indicators are intended to show how much progress has been made towards achieving sustainable development goals in countries. Each country involved in the study has developed its own independent system of indicators. It identifies exactly what sustainable development and the related strategy mean for them. 
Overally, it is sayable, both the European Union and its Member States are investing heavily in developing their own independent indicators. In the former process the national sustainable development strategy, the EU SDIs and the SDGs help them. Although in many cases this is only used as a solid basis.

\section{REFERENCES}

Bartus, G. (2013). A fenntartható fejlődés fogalom értelmezésének hatása az indikátorok kiválasztására [Impact of the concept of sustainable development on the choice of indicators - In Hungarian]. Statisztikai Szemle, 91(8-9), 842-869.

Bartus, G. \& Szalai, Á. (2014). Környezet, jog, közgazdaságtan. Környezetpolitikai eszközök, környezet-gazdaságtani modellek és joggazdaságtani magyarázatok [Environment, Law, Economics. Environmental policy tools, environmental economics models and legal economics explanations - In Hungarian]. Budapest: Pázmány Péter Katolikus Egyetem, Jog- és Államtudomány Kara.

Brokešová, Z. \& Vachálková, I. (2016). Macroeconomic environment and isurance industry development: The sace of Visegrad group countries. Ekonomická Revue. Central European Review of Economic Issues, 19, 63-72.

Central Statistical Office (2011). Sustainable Development Indicators for Poland. Katowice: Central Statistical Office.

Eurostat (2015). Sustainable Development in the European Union. 2015 Monitoring report of the EU Sustainable Development Strategy. Luxembourg: Publications Office of the European Union.

Eurostat (2017). Sustainable development in the European Union. Monitoring report on progress towards the SDGS in an EU context. Luxembourg: Publications Office of the European Union.

Fischer, J., Helman K., Kramulová, J., Petkovová, L., \& Zeman, J. (2013). Sustainable Development Indicators at the Regional Level in the Czech Republic. Statistika, 93(1), 518.

European Council Göteborg (2001). Conclusions of the Presidency - Göteborg._Retrieved August 6, 2017, from http://www.consilium.europa.eu/en/europeancouncil/conclusions/pdf-1993-2003/g\%C3\%96teborg-european-council--presidencyconclusions-15-16-june-2001/

Government Council for SD, Ministry of the Environment (2009). Progress Report on the Czech Republic Sustainable Development Strategy. Prague: EnviTypo.

Griggs, D., Stafford Smith, M., Rockström, J., Öhman, M. C., Gaffney, O., Glaser, G., ...Shyamsundar, P. (2014). An integrated framework for sustainable development goals. Ecology and society, 19(4) Art. 49.

Havasi, É. (2007). Az indikátorok, indikátorrendszerek jellemzői és statisztikai követelményei [Characteristics and statistical requirements of indicators, indicator systems - In Hungarian]. Statisztikai Szemle, 85(8), 676-689.

Izakovičová, Z. \& Oszlányi, J. (2009). Reflection on the concept of Sustainable Development: Progress in the Slovak Republic. In Mather, A. \& Bryden, J. (Ed.), Area Studies - Europe. Regional Sustainable Development Review (pp. 430-463). Oxford: EOLSS Publishers/UNESCO.

Káposzta, J. \& Nagy, H. (2015). Status report about the progress of the Visegrád countries in relation to Europe 2020 targets. European Spatial Research and Policy, 22(1), 81-99.

Kis-Orloczki, M. (2014). National Sustainable Development Strategies in the Visegrad Four. 
Electronic International Interdisciplinary Conference, Virtual Conference. 160-163. Retrieved March 25, 2019, from https://www.academia.edu/10502987/National_Sustainable_Development_Strategies_in the Visegrad Four

Koločány, F. (2014). Sustainable development in Slovakia in post-2000 period. Retrieved December 18, 2017, from network.eu/pdf/conferences/2014_rome/presentations/session\%205/Frantisek\%20Koloc any.pdf

Korsós-Schlesser, F. \& Marselek, S. (2016). Fenntarthatósági indikátorok változásainak elemzése Magyarországon, tekintettel a klímaváltozásra [Analysis of changes in sustainability indicators in Hungary with regard to climate change - In Hungarian]. Acta Carolus Robertus, 6(1), 105-116.

KSH (2017). A fenntartható fejlödés indikátorai Magyarországon, 2016 [Indicators of sustainable development in Hungary, 2016 - In Hungarian]. Budapest: Központi Statisztikai Hivatal.

Láng, I. (2001). Stockholm-Rió-Johannesburg. Lesz-e új a nap alatt a környezetvédelemben? [Will it be new in the environment protection during the day? - In Hungarian]. Magyar Tudomány, 46(12), 1415-1422.

Lyytimäki, J., Rinne, J., Kautto, P. \& Assmuth, T. (2011). Using indicators to assess sustainable development in the European Union, Finland, Malta and Slovakia. The Finnish Environment, 4, 1-78.

Magyar Természetvédők Szövetsége (2005). Az Unió fenntartható fejlödési stratégiájának végrehajtása és felülvizsgálata. Budapest: Magyar Természetvédők Szövetsége.

Ministry of the Environment of the Czech Republic (2010). The Strategic Framework for Sustainable Development in the Czech Republic. Prague: Ministry of the Environment of the Czech Republic.

NFÜ (2007). Nemzeti Fenntartható Fejlödési Stratégia [National Sustainable Development Strategy - In Hungarian]. Budapest: Magyar Köztársaság Kormánya.

NFFT (2013). Nemzeti Fenntartható Fejlödési Keretstratégia [National Sustainable Development Framework Strategy - In Hungarian]. Budapest: Nemzeti Fenntartható Fejlődési Tanács Titkára.

Office of the Government of the Czech Republic (2006). Interim Report on the Czech Republic Strategy for Sustainable Development. Prague: Office of the Government of the Czech Republic.

Puşcaciu, V., Puşcaciu, F. D. \& Puşcaciu, R.-M. (2016). Symmetries and Assymmetries in the Sustainable Development of European Union versus Romania. Acta Universitatis Danubius. Economica, 12(2), 245-254.

Rosta, I. (2008). A tudománytörténetéből - világproblémák, globalizáció. A Római Klub három jubileuma 2008-ban [From the history of science - world problems, globalization. The Three Anniversaries of the Club of Rome in 2008 - In Hungarian]. Magyar Tudomány, 169(12), 1516-1522.

Ruotsalainen, A. (2005). Review of National strategies for sustainable development in the Baltic Sea Region. Stockholm: Nordregio Working Paper.

Schmuck, E. (2002). Társadalmi vélemény és részvétel az EU-stratégia tervezési folyamatában [Social opinion and participation in the planning process of the EU strategy - In Hungarian]. In Faragó, T. (Ed.) Nemzetközi együttmüködés a fenntartható fejlödés jegyében és az Európai Unió fenntartható fejlödési stratégiája. Budapest: Fenntartható Fejlődés Bizottsága.

Stănciulescu, G. \& Bulin, D. (2012). Indicators of Sustainable Development - A Comparative Analysis between Bulgaria and Romania in European Context. International Journal of 
Economic Practices and Theories, 2(2), 91-98.

Štreimikiene D., Mikalauskiene A. \& Mikalauskas I. (2016). Comparative Assessment of Sustainable Energy Development in the Czech Republic, Lithuania and Slovakia. Journal of Competitiveness, 8(2), 31-41.

Urbaniec, M. (2015). Sustainable Development Indicators in Poland: Measurement and System Evaluation. Entrepreneurial Business and Economics Review, 3(1), 119-134.

WCED (1987). Our Common Future. London: Oxford University Press.

Zolcerova, V. (2016) From Stockholm or Rio to New York and Slovakia. Sustainable development agenda - Agenda 2030. Comenius Management Review, 10(1), 23-32.

Zuzek, D. (2007). Economic and social aspects of the Sustainable Development Strategy for Poland up to 2025. Management and Sustainable Development, 17(2), 56-59. 